\title{
Status of neutrophil-lymphocyte ratio and 25-hydroxyvitamin D in preeclampsia and preterm birth
}

\author{
Lebriz Hale Tamer', Yeliz Aykanat', Fulya Gökdağlı Sağır', Oktay Olmuşçelik², Suna Özdemir \\ ${ }^{1}$ Department of Obstetrics and Gynecology, Faculty of Medicine, Istanbul Medipol University, Istanbul, Turkey \\ ${ }^{2}$ Department of Internal Medicine, Faculty of Medicine, Istanbul Medipol University, Istanbul, Turkey
}

\begin{abstract}
Objective: To examine the effect of low 25-hydroxyvitamin D (25$\mathrm{OH} \mathrm{D})$ levels and the neutrophil-to-lymphocyte ratios (NLRs) on preeclampsia and preterm birth.

Methods: A total of 180 pregnant women who gave birth at the Istanbul Medipol University Gynecology and Obstetrics Clinic between 2014 and 2017 were enrolled in the study. The study group consisted of 61 preeclamptic women $(n=61)$ and 74 women $(n=74)$ with preterm births, and the control group consisted of 45 women $(n=45)$ with term births. The demographic, obstetric and laboratory results of all three groups were compared according to 25-OH D levels and NLRs.

Results: There was no statistically significant difference among the three groups in terms of BMI, abortus numbers and socioeconomic status ( $>0.05$ ). Maternal age, gravida, parity, gestational week, birth weight and Apgar scores were significantly lower in the preeclamptic and preterm groups compared to the control group $(\mathrm{p}<0.05) .25-$ $\mathrm{OH} \mathrm{D}$ levels were found to be significantly lower in preeclamptic and preterm pregnancies compared to term pregnancies $(18.2 \pm 4.3$ $\mathrm{ng} / \mathrm{ml} ; 19.1 \pm 3.7 \mathrm{ng} / \mathrm{ml} ; 34 \pm 5.1 \mathrm{ng} / \mathrm{ml}, \mathrm{p}<0.05$, respectively) while the NLR was significantly higher in the preeclampsia and preterm birth group compared to the term birth group (3.96 $\pm 1.23,3.98$ $\pm 1.34,3.22 \pm 1.24$, $\mathrm{p}<0.05$, respectively).

Conclusion: Low levels of 25-OH D and increased NLR are likely to play a role in spontaneous preterm birth and preeclampsia etiology. The impact of maternal vitamin D supplementation on the improvement of maternal, fetal and neonatal health is not clear, but more extensive research is needed on the potential positive effects.
\end{abstract}

Keywords: Vitamin D, neutrophil-lymphocyte ratio, preeclampsia, preterm birth.

\section{Özet: Preeklampsi ve preterm doğumda nötrofil-lenfosit oranı ve $\mathbf{2 5}$ hidroksi D vitamini durumu}

Amaç: Preeklampsi ve preterm doğumda düşük 25 hidroksi $\mathrm{D}$ vitamini (25-OH D) seviyelerini ve nötrofil-lenfosit oranlarını (NLO) incelemektir.

Yöntem: İstanbul Medipol Üniversitesi Kadın Hastalıkları ve Doğum Kliniği'nde 2014 - 2017 yılları arasında doğum yapan toplam 180 gebe çalışmaya dahil edildi. Çalışma grubu 61 preeklamptik gebeden $(n=61)$ ve preterm doğum yapan 74 kadindan $(n=74)$, kontrol grubu ise miadında doğum yapan 45 kadından $(n=45)$ oluşuyordu. Üç grubun demografik, obstetrik ve laboratuvar sonuçlar1, 25-OH D seviyeleri ve NLO bakımından karşılaştırıldı.

Bulgular: VKİ, düşük sayısı ve sosyoekonomik durum yönünden üç grup arasında istatistiksel olarak anlamlı farklılık yoktu ( $>0.05$ ). Maternal yaş, gravida, parite, gebelik haftası, doğum ağırlığı ve Apgar skorları, kontrol grubuna kıyasla preeklamptik ve preterm grupta anlamlı şekilde daha düşüktü $(\mathrm{p}<0.05)$. 25-OH D seviyeleri, miad gebeliklere klyasla preeklamptik ve preterm gebeliklerde anlamlı şekilde daha düşükken (sırasıyla $18.2 \pm 4.3 \mathrm{ng} / \mathrm{ml}$; $19.1 \pm 3.7 \mathrm{ng} / \mathrm{ml} ; 34 \pm 5.1 \mathrm{ng} / \mathrm{ml}, \mathrm{p}<0.05$ ), NLO ise miad doğum grubuna kıyasla preeklampsi ve preterm doğum gruplarında anlamlı şekilde daha yüksekti (sırasıyla $3.96 \pm 1.23,3.98 \pm 1.34,3.22 \pm$ $1.24, \mathrm{p}<0.05)$.

Sonuç: Düşük 25-OH D seviyeleri ve artmış NLO'nun, spontane preterm doğum ve preeklampsi etiyolojisinde rol oynaması muhtemeldir. Maternal D vitamini takviyesinin maternal, fetal ve neonatal sağlığın gelişmesi üzerindeki etkisi belirsizdir, ancak potansiyel olumlu etkiler üzerine daha kapsamlı araştırma gerekmektedir.

Anahtar sözcükler: D vitamini, nötrofil-lenfosit oranı, preeklampsi, preterm doğum.
Correspondence: Lebriz Hale Tamer, MD. Department of Obstetrics and Gynecology, Faculty of Medicine, Istanbul Medipol University, Istanbul, Turkey. e-mail: lebrizhale@gmail.com Received: July 18, 2017; Accepted: October 24, 2017

Please cite this article as: Tamer LH, Aykanat Y, Gökdağlı Sağır F, Olmuşçelik O, Özdemir S. Status of neutrophil-lymphocyte ratio and 25-hydroxyvitamin D in preeclampsia and preterm birth. Perinatal Journal 2017;25(3):91-96.
Available online at: www.perinataljournal.com/20170253001 doi: $10.2399 /$ prn.17.0253001 QR (Quick Response) Code:

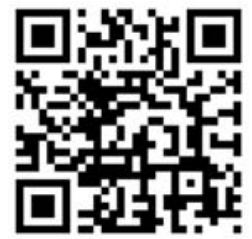




\section{Introduction}

Vitamin D plays an important role in calcium homeostasis and bone metabolism. ${ }^{[1,2]}$ Vitamin D status and season are intrinsically linked; upon exposure to natural sunlight, endogenous skin production of vitamin D occurs. ${ }^{[3,4]}$ Serum 25 -hydroxyvitamin D $(25-\mathrm{OH} \mathrm{D})$ is usually measured to assess vitamin D levels. 25-OH D is the active form of 1.25-dihydroxyvitamin $\mathrm{D}$ and it has a half-life of 4-6 hours, while the half-life of 25$\mathrm{OH} \mathrm{D}$ has been determined to be about $2-3$ weeks. ${ }^{[5-7]}$ Recent studies have shown that 25-OH D is responsible for many important metabolic pathways in addition to its well-defined role in bone-calcium metabolism. It has already been shown to play an important role in apoptosis, antiproliferative pathways, immunosuppression and also exert anti-inflammatory effects on many different tissues such as the brain, reticulo-endotelial system, urogenital system. Moreover, it has already been shown to impact the etiology of different systemic inflammatory diseases, type 2 diabetes, depression and autoimmune diseases. ${ }^{[8-1]]}$ The neutrophil-to-lymphocyte ratio (NLR) has been defined as a useful marker for systemic inflammatory diseases. Even in the appropriate climate circumstances, 25-OH D deficiency is still a challenging topic. Studies indicating the role of $25-\mathrm{OH} \mathrm{D}$ deficiency during pregnancy and its relation with hypertensive diseases, diabetes, and preterm birth are rapidly increasing. Hypertension during pregnancy (prevalence: $5-10 \%$ ) is responsible for serious morbidity and mortality. ${ }^{[12]}$ Hypertension in pregnancy can present as gestational hypertension, preeclampsia and eclampsia. ${ }^{[13]}$ Endothelial dysfunction, oxidative stress and inflammation play a critical role in increasing the risk of hypertensive diseases during pregnancy. ${ }^{[14]}$ Low levels of $25-\mathrm{OH} \mathrm{D}$ in pregnancy can play a role in maternal preeclampsia, diabetes, cholestasis, periodontal disease, intrauterine growth retardation, premature birth and cesarean birth. Maternal 25-OH D deficiency is a well-defined risk factor for rickets in newborns and early childhood. It has also been suggested that 25$\mathrm{OH} \mathrm{D}$ leads to type 1 diabetes, asthma, allergy, multiple sclerosis and schizophrenia later in life. In this respect, vitamin D supplementation during pregnancy has become an important treatment strategy in order to eliminate early and late-stage health problems. Hypertensive diseases during pregnancy have been shown to boost the metabolism of creatinine and uric acid levels and decrease the serum calcium due to metabolic changes. 25-OH D exerts angiogenic, immunmodulator and anti-inflammatory roles for implantation and placentation. ${ }^{[15,16]}$ Some studies have shown that high levels of $25-\mathrm{OH} \mathrm{D}$ are particularly protective for preeclampsia. ${ }^{[17-22]}$ In this context, it has been suggested that a severe deficiency of $25-\mathrm{OH} \mathrm{D}$ below $10 \mathrm{ng} / \mathrm{ml}$ may increase the risk of preeclampsia and eclampsia during pregnancy. ${ }^{[23]}$ The ideal recommendations for screening and supplementation are still controversial. The aim of the study is to investigate relationship between 25-OH D levels and NLRs in preterm labor and preeclampsia.

\section{Methods}

A total of 180 pregnant women, who gave birth at the Istanbul Medipol University Gynecology and Obstetrics Clinic between 2014 and 2017, were enrolled in the study. The study group consisted of 61 women $(n=61)$ with preeclampsia as group 1 and 74 women $(n=74)$ with preterm birth as group 2, and control group consisted of 45 women $(n=45)$ with term birth as group 3 . The demographic, obstetric and laboratory results of all three groups were compared in terms of $25-\mathrm{OH} \mathrm{D}$ levels and NLRs.

The diagnosis of preeclampsia was made according to the criteria of American Collage of Obstetricians and Gynecologists (ACOG) guideline for hypertension in pregnancy. Preeclampsia was defined as the condition in which arterial blood pressure levels were greater than or equal to $140 \mathrm{mmHg}$ systolic and/or $90 \mathrm{mmHg}$ diastolic on two occasions at least 4 hours apart and proteinuria after the 20th week of pregnancy, greater than or equal to $300 \mathrm{mg} / \mathrm{dl}$ per 24-hour urine collection or dipstick reading of $1+$ or more. Preterm birth was defined as the delivery of a liveborn infant before 37 weeks of gestation. Patients with history of metabolic disease, uterine anomalies, multiple pregnancies, fetal anomalies, intrauterine growth retardation, pregestational and gestational diabetes, membrane rupture, chorioamnionitis, fetal tachycardia or fever with an unknown origin were excluded.

The control group consisted of healthy pregnant women who gave birth between gestational week 37 and 42 without any medical condition or poor obstetric trait (diabetes, hypertension, obesity or small for gestational age history in previous births). Blood samples were collected in the labor room. The clinical parameters included age, body mass index, socio-economic status, gravida, 
Table 1. Comparison of demographic and clinical data between groups.

\begin{tabular}{|c|c|c|c|c|}
\hline & $\begin{array}{c}\text { Group } 1 \\
(n=61)\end{array}$ & $\begin{array}{c}\text { Group } 2 \\
(n=74)\end{array}$ & $\begin{array}{c}\text { Group } 3 \\
(n=45)\end{array}$ & $\begin{array}{c}p \\
\text { value }\end{array}$ \\
\hline Maternal age (years) & $23.7 \pm 2.4^{\dagger}$ & $22.5 \pm 2.1^{\dagger}$ & $29.2 \pm 3.1$ & $<0.001 *$ \\
\hline Gravida & $2(0-2)^{+}$ & $2(0-2)^{+}$ & $3(1-8)$ & $<0.001 *$ \\
\hline Parity & $1(0-3)^{\dagger}$ & $1(0-3)^{\dagger}$ & $2(0-6)$ & $<0.001 *$ \\
\hline Abortus & $1(0-3)^{\dagger}$ & $1(0-3)^{\dagger}$ & $2(0-6)$ & $<0.001 *$ \\
\hline The gestational weeks at delivery & $0(0-3)$ & $0(0-2)$ & $0(0-3)$ & NS \\
\hline BMI $\left(\mathrm{kg} / \mathrm{m}^{2}\right)$ & $22.9 \pm 3.2$ & $22.7 \pm 3.5$ & $23.1 \pm 2.9$ & NS \\
\hline \multicolumn{5}{|l|}{ Socio-economic status } \\
\hline Low & $19 \%$ & $18 \%$ & $19 \%$ & NS \\
\hline Medium & $63 \%$ & $65 \%$ & $64 \%$ & NS \\
\hline High & $18 \%$ & $17 \%$ & $17 \%$ & NS \\
\hline Birth weight (g) & $2445 \pm 280^{+}$ & $2100 \pm 370^{+}$ & $3320 \pm 310$ & $<0.001 *$ \\
\hline \multicolumn{5}{|l|}{ Apgar score } \\
\hline 1. minute & $7.2 \pm 1.1^{\dagger}$ & $7.0 \pm 1.2^{\dagger}$ & $8.8 \pm 0.5$ & $<0.001 *$ \\
\hline 5. minute & $8.2 \pm 0.7^{\dagger}$ & $7.8 \pm 0.6^{+}$ & $9.7 \pm 0.2$ & $<0.001$ * \\
\hline
\end{tabular}

Mean \pm SD, mean (min-max). BMI: body mass index; n: number (\%); NS: no statistical significance.

*Statistical significance; ${ }^{\dagger}$ statistical significance was based on healthy pregnant group $(p<0.05)$.

parity, gestational age, abortus neonatal weight and 1-5 minute Apgar scores.

\section{Laboratory analysis}

Venous blood samples were collected in the labor room. Serum 25-OH D was measured in the auto-analyzer (Cobas 6000; Roche, Tokyo, Japan) with the electrochemiluminescence immunoassay method (ECLIA). 30$80 \mathrm{ng} / \mathrm{ml}$ was evaluated as optimal and $20 \mathrm{ng} / \mathrm{ml}$ deficient, 20-29 $\mathrm{ng} / \mathrm{ml}$ insufficiency and $<15 \mathrm{ng} / \mathrm{ml}$ was considered as toxic. The results were calculated as standard deviations. The hemogram values were analyzed on an automated hematology device (XT2000i; Symex, Osaka, Japan).

Statistical analysis: The data was analyzed using Statistical Package Social Sciences (SPSS) Version 15.0 (SPSS Inc., Chicago, IL, USA). Descriptive statistics were expressed as standard deviations and averages for numerical variables. The Kolmogorov-Smirnov test was used to analyze the regular distribution of variables and the Mann-Whitney $U$ test was performed for subgroup comparisons. The Pearson's chi-square test was used for categorical variables. The p-value $<0.05$ was considered to be significant. The one-way ANOVA (Robust test: Brown-Forsythe) and Kruskal-Wallis $\mathrm{H}$ test post hoc analysis and the nonparametric post hoc tests (Miller, 1966) were adopted for multiple group comparisons.

\section{Results}

The comparisons of socio-demographic and clinical data of the groups are presented in Table $\mathbf{1}$. There was no statistically significant difference among the three groups in terms of BMI, abortus number and socioeconomic status $(\mathrm{p}>0.05)$. Maternal age, gravida, parity, gestational week, birthweight and Apgar scores were significantly lower in the preeclamptic and preterm groups compared to the control group $(\mathrm{p}<0.05)$. A comparison of the laboratory values of the groups is presented in Table 2. 25-OH D levels were signifi-

Table 2. Comparison of laboratory data.

\begin{tabular}{lcccc} 
& $\begin{array}{c}\text { Group 1 } \\
(\mathbf{n}=61)\end{array}$ & $\begin{array}{c}\text { Group 2 } \\
(\mathbf{n}=\mathbf{7 4})\end{array}$ & $\begin{array}{c}\text { Group 3 } \\
(\mathbf{n}=45)\end{array}$ & $\begin{array}{c}\mathbf{p} \\
\text { value }\end{array}$ \\
\hline 25-OH vitamin D $(\mathrm{ng} / \mathrm{ml})$ & $18.2 \pm 4.3^{+}$ & $19.1 \pm 3.7^{\dagger}$ & $34 \pm 5.1$ & $0.001^{*}$ \\
NLR & $3.96 \pm 1.23^{+}$ & $3.98 \pm 1.34^{+}$ & $3.22 \pm 1.24$ & $0.005^{*}$ \\
\hline
\end{tabular}

*Statistical significance; ${ }^{\dagger}$ statistical significance was based on healthy pregnant group $(p<0.05)$. 
cantly lower in the preeclamptic and preterm group compared to the control group $(\mathrm{p}<0.05)$ and NLRs were found to be higher in the preterm and preeclampsia group compared to the control group $(\mathrm{p}<0.05)$.

\section{Discussion}

25-OH D deficiency during pregnancy is critical both for fetal and maternal outcomes. The prevalence of preeclampsia, preterm birth and metabolic diseases such as gestational diabetes has been shown to be increased in pregnancies with severe 25-OH D deficiency, especially within the first trimester of the antepartum period. Hollis et al. evaluated the effect of vitamin D supplementations which were applied in three different doses of 400, 2000 and $4000 \mathrm{IU}$ to 350 pregnant women in their first trimester. They have interestingly showed that there was no significant difference between 2000 and $4000 \mathrm{IU}$ while there was a significant difference between a low dose and a high dose of supplementation in terms of pregnancy outcomes. Despite this promising clinical data, there is some disagreement on the dosing regimens in pregnancies which is related to its well-known effects in terms of deficiency. ${ }^{[2]]}$

In our study, we aimed to investigate the relationship between preterm birth, preeclampsia and 25-OH D deficiency. We concluded that maternal 25-OH D serum levels decreased as an inflammatory and oxidative stress marker in preeclamptic and preterm birth group. We have found no significant difference in the demographic characteristics of the patients when compared to the control group. When considering the outcomes of the preeclampsia group, our results are in line with many studies showing that vitamin $\mathrm{D}$ levels are lower than the control groups.

In the light of recent controversial results regarding the relationship between vitamin D levels and preterm birth, we concluded that the levels of vitamin D in preterm birth were decreased. Our results highlight the importance of vitamin $\mathrm{D}$ deficiency. In accordance with this, a study carried out by Parlak et al. in Turkey observed pregnant women who were vitamin D deficient and compared them in terms of poor socio-economic status, number of pregnancies and style of dress. It was concluded that primiparous women with a conservative style of dress and poor economic status had an increased risk of 25-OH D deficiency. The study highlighted the importance of vitamin $\mathrm{D}$ supplementation for this population that makes up a major part of pregnant women in Turkey. ${ }^{[25]}$ We agree with the results of this study which recommend a daily supplementation of 1500 to 2000 IU during pregnancy and the postpartum period. As suggested by Bodnar et al. which is replicated in many studies of the literature, the diagnosis and prevention of vitamin D deficiency at an early stage can halt/decrease preterm birth rates. In our study, we concluded that there is a significant difference between patients with low levels of 25-OH D and the control group in terms of preterm birth risk. ${ }^{[26]}$ Moreover, Schulz et al. conducted a study on the relationship between 25-OH D deficiency and placentation. They revealed that vitamin $\mathrm{D}$ plays a critical role in the formation of vascular pathologies. A recent study suggests that sFlt-1 plays a significant role in the formation of preeclampsia, through its relationship with VEGF expression. It has been proposed that vitamin D supplementation potentially decreases the levels of antiangiogenic factors via the placental gene transcription. ${ }^{[27]}$

Cakmak et al. has shown that epicardial fat thickness, pentraxin-3 and NLR may be useful inflammatory markers in terms of evaluating preeclampsia. ${ }^{[28]} \mathrm{A}$ retrospective study compared first trimester levels of NLR and platelet to lymphocyte ratios (PLR) in preeclamptic women and health controls. They suggested that high NLR and PLR during the first trimester are independent predictors of subsequent preeclampsia. ${ }^{[2]]}$ In another retrospective study, Kim et al. evaluated 483 preterm births. These preterm birth cases were divided into two groups as women with and without placental inflammatory response. The researchers concluded that NLR is a cost-effective parameter in women with placental inflammatory response in terms of admission to delivery interval. ${ }^{[30]}$ Jung et al. showed pre-operative increased NLR and amniotic fluid IL-8 levels in preterm births before 32 weeks after emergency cerclage and they suggested that they may be important markers for predicting emergency cerclage outcomes in women with cervical insufficiency. ${ }^{[3]}$ Kim et al. designed a combined marker by dividing cervical length by NLR and showed that combined marker was more sensitive than C-reactive protein (CRP), NLR and cervical length alone for predicting the risk of preterm labor. ${ }^{[3]}$ Also, maternal NLR was found to independently predict the risk of NEC in very preterm infants, whereas clinical and histological chorioamnionitis and funisitis are not predic- 
tive of NEC. ${ }^{[33]}$ In light of the above mentioned data, our study also suggests increased NLR is a marker of systemic inflammatory disease in preterm and preclamptic patient groups.

From a critical point of view, as a weakness of the study, we excluded iatrogenic preterm birth. Thus, we processed the data only on spontaneous preterm birth. Further studies evaluating the correlation between NLR and vitamin $\mathrm{D}$ deficiency are urgently warranted.

\section{Conclusion}

In conclusion, we suggest that vitamin D supplementation can be administered to pregnant women although there is still no consensus on this issue. Moreover, NLR can be evaluated as an important parameter for diseases in which systemic inflammation is predominant, but needs validation by prospective multicenter studies.

Conflicts of Interest: No conflicts declared.

\section{References}

1. Vogeser M. Quantification of circulating 25-hydroxyvitamin $\mathrm{D}$ by liquid chromatography-tandem mass spectrometry. J Steroid Biochem Mol Biol 2010;121:565-73.

2. Moy FM, Bulgiba A. High prevalence of vitamin D insufficiency and its association with obesity and metabolic syndrome among Malay adults in Kuala Lumpur, Malaysia. BMC Public Health 2011;11:735.

3. van der Meer IM, Middelkoop BJC, Boeke AJ, Lips P. Prevalence of vitamin D deficiency among Turkish, Moroccan, Indian and sub-Sahara African populations in Europe and their countries of origin: an overview. Osteoporos Int 2011;22:100921.

4. Shea MK, Houston DK, Tooze JA, Davis CC, Johnson MA, Hausman DB, et al.; Health, Aging and Body Composition Study. Correlates and prevalence of insufficient 25-hydroxyvitamin D status in black and white older adults: the health, aging and body composition study. J Am Geriatr Soc 2011;59: $1165-74$.

5. Mallah EM, Hamad MF, Elmanaseer MA, Qinna NA, Idkaidek NM, Arafat TA, et al. Plasma concentrations of 25-hydroxyvitamin D among Jordanians: effect of biological and habitual factors on vitamin D status. BMC Clin Pathol 2011;11:8.

6. Vu LH, Whiteman DC, van der Pols JC, Kimlin MG, Neale RE. Serum vitamin D levels in office workers in a subtropical climate. Photochem Photobiol 2011;87:714-20.

7. Wang TJ. Vitamin D and cardiovascular disease. Annu Rev Med 2016;67:261-72.

8. Ringe JD. The effect of Vitamin D on falls and fractures. Scand J Clin Lab Invest Suppl 2012;243:73-8.
9. Rosen Y, Daich J, Soliman I, Brathwaite E, Shoenfeld Y. Vitamin D and autoimmunity. Scand J Rheumatol 2016;45: 439-47.

10. Nakashima A, Yokoyama K, Yokoo T, Urashima M. Role of vitamin $\mathrm{D}$ in diabetes mellitus and chronic kidney disease. World J Diabetes 2016;7:89-100.

11. Okereke OI, Singh A. The role of vitamin D in the prevention of late-life depression. J Affect Disord 2016;198:1-14.

12. Berhan Y. No hypertensive disorder of pregnancy; no preeclampsia-eclampsia; no gestational hypertension; no hellp syndrome. Vascular disorder of pregnancy speaks for all. Ethiop J Health Sci 2016;26:177-86.

13. Mammaro A, Carrara S, Cavaliere A, Ermito S, Dinatale A, Pappalardo EM. Hypertensive disorders of pregnancy. J Prenat Med 2009;37:1-5.

14. Garovic VD, Hayman SR. Hypertension in pregnancy: an emerging risk factor for cardiovascular disease. Nat Clin Pract Nephrol 2007;3:613-22.

15. Zhao X, Fang R, Yu R, Chen D, Zhao J, Xiao J. Maternal vitamin $\mathrm{D}$ status in the late second trimester and the risk of severe preeclampsia in Southeastern China. Nutrients 2017;9. pii:E138.

16. Ota K, Dambaeva S, Han AR, Beaman K, Gilman-Sachs A, Kwak-Kim J. Vitamin D deficiency may be a risk factor for recurrent pregnancy losses by increasing cellular immunity and autoimmunity. Hum Reprod 2014;29:208-19.

17. Baker AM, Haeri S, Camargo CA Jr, Espinola JA, Stuebe AM. A nested case-control study of midgestation vitamin D deficiency and risk of severe preeclampsia. J Clin Endocrinol Metab 2010;95:5105-9.

18. Bodnar LM, Catov JM, Simhan HN, Holick MF, Powers RW, Roberts JM. Maternal vitamin D deficiency increases the risk of preeclampsia. J Clin Endocrinol Metab 2007;92:351722.

19. Robinson CJ, Wagner CL, Hollis BW, Baatz JE, Johnson DD. Association of maternal vitamin D and placenta growth factor with the diagnosis of early onset severe preeclampsia. Am J Perinatol 2013;30:167-72.

20. Wei SQ, Audibert F, Hidiroglou N, Sarafin K, Julien P, Wu $\mathrm{Y}$, et al. Longitudinal vitamin $\mathrm{D}$ status in pregnancy and the risk of pre-eclampsia. BJOG 2012;119:832-9.

21. Marya RK, Rathee S, Manrow M. Effect of calcium and vitamin D supplementation on toxaemia of pregnancy. Gynecol Obstet Invest 1987;24:38-42.

22. Robinson CJ, Alanis MC, Wagner CL, Hollis BW, Johnson DD. Plasma 25-hydroxyvitamin D levels in early-onset severe preeclampsia. Am J Obstet Gynecol 2010;203:366.e1-6.

23. Baker AM, Haeri S, Camargo CA Jr, Espinola JA, Stuebe AM. A nested case-control study of midgestation vitamin D deficiency and risk of severe preeclampsia. J Clin Endocrinol Metab 2010;95:5105-9.

24. Hollis BW, Johnson D, Hulsey TC, Ebeling M, Wagner CL. Vitamin D supplementation during pregnancy: double-blind, randomized clinical trial of safety and effectiveness. J Bone Miner Res 2011;26:2341-57. 
25. Parlak M, Kalay S, Kalay Z, Kirecci A, Guney O, Koklu E. Severe vitamin $\mathrm{D}$ deficiency among pregnant women and their newborns in Turkey. J Matern Fetal Neonatal Med 2015;28: 548-51.

26. Bodnar LM, Platt RW, Simhan HN. Early-pregnancy vitamin $\mathrm{D}$ deficiency and risk of preterm birth subtypes. Obstet Gynecol 2015;125:439-47.

27. Schulz EV, Cruze L, Wei W, Gehris J, Wagner CL. Maternal vitamin $\mathrm{D}$ sufficiency and reduced placental gene expression in angiogenic biomarkers related to comorbidities of pregnancy. J Steroid Biochem Mol Biol 2017;173:273-9.

28. Cakmak HA, Dincgez Cakmak B, Abide Yayla C, Inci Coskun E, Erturk M, Keles I. Assessment of relationships between novel inflammatory markers and presence and severity of preeclampsia: epicardial fat thickness, pentraxin-3, and neutrophil-to-lymphocyte ratio. Hypertens Pregnancy 2017;36: 233-9.
29. Gezer C, Ekin A, Ertas IE, Ozeren M, Solmaz U, Mat E, et al. High first-trimester neutrophil-to-lymphocyte and plateletto-lymphocyte ratios are indicators for early diagnosis of preeclampsia. Ginekol Pol 2016;87:431-5.

30. Kim MA, Lee YS, Seo K. Assessment of predictive markers for placental inflammatory response in preterm births. PLoS One 2014;9:e107880.

31. Jung EY, Park KH, Lee SY, Ryu A, Joo JK, ParkJW. Predicting outcomes of emergency cerclage in women with cervical insufficiency using inflammatory markers in maternal blood and amniotic fluid. Int J Gynaecol Obstet 2016;132: 165-9.

32. Kim MA, Lee BS, Park YW, Seo K. Serum markers for prediction of spontaneous preterm delivery in preterm labour. Eur J Clin Invest 2011;41:773-80.

33. Lee JY, Park KH, Kim A, Yang HR, Jung EY, Cho SH. Maternal and placental risk factors for developing necrotizing enterocolitis in very preterm infants. Pediatr Neonatol 2017;58: $57-62$. 